\title{
Multidrug resistance and risk factors associated with community-acquired urinary tract infections caused by Escherichia coli in Venezuela
}

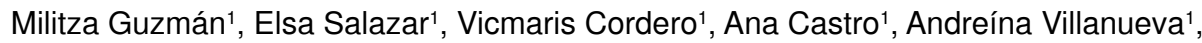 \\ Hectorina Rodulfo ${ }^{2,3}$, Marcos De Donato ${ }^{2,3}$ \\ ${ }^{1}$ Laboratorio de Bacteriología Molecular, Departamento de Bioanálisis, Universidad de Oriente, \\ Cumaná, Venezuela \\ ${ }^{2}$ Laboratorio de Genética Molecular, Instituto de Investigaciones en Biomedicina y Ciencias \\ Aplicadas Dra. Susan Tai (IIBCAUDO) Universidad de Oriente, Cumaná, Venezuela \\ ${ }^{3}$ Tecnológico de Monterrey, Escuela de Ingeniería y Ciencias, Querétaro, México
}

Introduction: The treatment of urinary tract infections has become more challenging due to the increasing frequency of multidrug-resistant Escherichia coli in human populations.

Objective: To characterize multidrug-resistant $E$. coli isolates causing community-acquired urinary tract infections in Cumaná, Venezuela, and associate possible risk factors for infection by extended-spectrum beta-lactamases (ESBL)-producing isolates.

Materials and methods: We included all the patients with urinary tract infections attending the urology outpatient consultation and emergency unit in the Hospital de Cumaná, Estado Sucre, Venezuela, from January through June, 2014. bla $a_{\mathrm{TEM}}$, bla $a_{\mathrm{SHV}}$ and bla $a_{\mathrm{CTX}-\mathrm{M}}$ genes detection was carried out by PCR.

Results: We found a high prevalence of multidrug-resistant E. coli $(25.2 \%)$ with $20.4 \%$ of the isolates producing ESBL. The ESBL-producing isolates showed a high frequency $(66.7 \%)$ of simultaneous resistance to trimethoprim-sulphamethoxazole, fluoroquinolones and aminoglycosides compared to non-producing isolates (2.4\%). Of the resistant isolates, $65.4 \%$ carried the $b / a_{\text {TEM }}$ gene, $34.6 \%$ the $b / a_{\text {CTX-M }}$ and $23.1 \%$ the $b l a_{\text {SHV }}$. The $b l a_{\text {CTX-M }}$ genes detected belonged to the CTX-M-1 and CTX-M-2 groups. Plasmid transfer was demonstrated by in vitro conjugation in 17 of the 26 ESBL-producing isolates. All three genes detected were transferred to the transconjugants. Age over 60 years, complicated urinary tract infections and previous use of a catheter predisposed patients to infection by ESBL-producing E. coli.

Received: $22 / 08 / 17$

Accepted: $31 / 08 / 18$

Published: 04/09/18

Citation:

Guzmán M, Salazar E, Cordero V, Castro A, Villanueva A, Rodulfo H, De Donato M. Multidrug resistance and risk factors associated with community-acquired urinary tract infections caused by Escherichia coli in Venezuela. Biomédica. 2019;39(Supl.1):96-106 https://doi.org/10.7705/biomedica.v39i2.4030

Corresponding author:

Marcos De Donato, Escuela de Ingeniería y Ciencias, Tecnológico de Monterrey, Avenida Epigmenio Gonzalez 500, Querétaro, México, 76130 Telephone: (+52) (442) 2383100

mdedonate@itesm.mx

\section{Author contributions:}

Militza Guzmán, Elsa Salazar: experiment design, strains identification, and antimicrobial assays. Vicmaris Córdero, Ana Castro: collection of samples and epidemiological data, strains identification, antimicrobial assays.

Militza Guzmán, Andreína Villanueva, Hectorina Rodulfo, Marcos De Donato: molecular analyses. Militza Guzmán, Marcos De Donato: data analysis, manuscript wrting

\section{Funding:}

The authors would like to thank the Consejo de Investigaciones of the Universidad de Oriente for funding and supporting this project (number: $\mathrm{Cl}-2$ 040102-1409/08).

\section{Conflicts of interest}

None of the authors report any conflicts of interest.
Conclusions: The high frequency of multidrug-resistant ESBL-producing isolates should alert the regional health authorities to take measures to reduce the risk of outbreaks caused by these types of bacteria in the community.

Keywords: Escherichia coli; urologic diseases; beta-lactamases; rug resistance, bacterial; community-acquired infections.

\section{Multirresistencia a medicamentos y factores de riesgo asociados con infecciones urinarias por Escherichia coli adquiridas en la comunidad, Venezuela}

Introducción. El tratamiento de las infecciones urinarias constituye un reto creciente por el aumento de Escherichia coli proveniente de la comunidad multirresistente a los medicamentos.

Objetivo. Caracterizar aislamientos de E. coli multirresistente causantes de infecciones urinarias adquiridas en la comunidad en Cumaná, Venezuela, y detectar los posibles riesgos de infección por aislamientos productores de betalactamasas de espectro extendido (BLEE).

Materiales y métodos. Se incluyeron todos los pacientes atendidos en la consulta externa de urología y en urgencias del Hospital de Cumaná entre enero y junio de 2014 y que evidenciaban infecciones urinarias. La detección de los genes $b l a_{\mathrm{TEM}}$, bla $a_{\mathrm{SHV}}$ y bla $a_{\mathrm{CTX}-\mathrm{M}}$ se hizo mediante la reacción en cadena de la polimerasa (PCR).

Resultados. Se encontró una alta prevalencia de $E$. coli multirresistente a los medicamentos $(25,2 \%)$, con $20,4 \%$ de aislamientos productores de BLEE y una gran frecuencia de resistencia simultánea a trimetoprim-sulfametoxazol, fluoroquinolonas y aminoglucósidos $(66,7 \%)$ comparados con los no productores (2,4\%). En el $65,4 \%$ de los aislamientos resistentes, se encontró el gen bla $a_{\mathrm{TEM}}$; en $34,6 \%$, el bla $a_{\mathrm{CTX}-\mathrm{M}}$, y en $23,1 \%$, el bla ${ }_{\mathrm{SHV}}$. Los

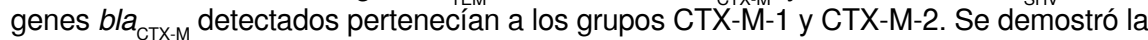
transferencia in vitro de plásmidos por conjugación en 17 de los 26 aislamientos productores de BLEE. Los tres tipos de genes detectados se transfirieron a los transconjugantes. La edad mayor de 60 años, las infecciones urinarias con complicaciones y el uso previo de catéter, predispusieron a la infección por cepas de E. coli productoras de BLEE. 
Conclusiones. La gran frecuencia de aislamientos multirresistentes productores de BLEE debería alertar a las autoridades sanitarias para tomar medidas que reduzcan el riesgo de epidemias causadas por este tipo de bacterias en la comunidad.

Palabras clave: Escherichia coli; enfermedades urológicas; beta-lactamasas; farmacorresistencia bacteriana; infecciones comunitarias adquiridas.

Urinary tract infections affect people of all ages and are one of the most frequently treated pathologies in primary healthcare centers. Although urinary infections can be caused by several species in the Enterobacteriaceae, most cases (both community and hospital-acquired) are produced by $E$. coli $(1,2)$. Infection rates by extended-spectrum $\beta$-lactamases (ESBL)-producing $E$. coli have increased in the last 10 years in Latin America, with some regions showing prevalences of up to $32 \%$. In addition, 11 to $25 \%$ of these ESBL-producing $E$. coli infections are now resistant to third generation cephalosporins including important rates of multidrug resistance, and only the antibiotics carbapenems, tigecycline and colistin are showing susceptibility rates $>90 \%$ (3).

ESBL-producing strains are also often resistant to antibiotics of other classes (sulfonamides, aminoglycosides, quinolones) thus complicating treatment strategies. The screening of ESBL-producing bacteria by antibiotic susceptibility testing is challenging, hence detection of specific genes by PCR is commonly used for final confirmation. The most common ESBL are the SHV, TEM, and CTX-M types, and the association of these three types of enzymes with $E$. coli infections has been investigated in many studies. CTX-M-type enzymes have been shown to be the most prevalent ESBL (4) and have been associated with numerous outbreaks of infections both in hospitals and in the community, and particularly, along with the SHV and TEM types, in urinary $E$. coli strains isolated from nonhospital settings (5). This has resulted in a change in epidemiological patterns with ESBL-producing strains appearing outside the hospital environment, thus converting them into an emerging public health problem $(2,6)$. The frequencies of ESBL found in South America rank amongst the highest in the world with CTX-M dominant possibly due to poorer social and economic situations, hospital overcrowding, lack of antimicrobial stewardship, excessive over-the-counter antibiotic usage, and under-supported infection control practices (6).

In Venezuela, there are several reports of infections by ESBL-producing Enterobacteriaceae species from Caracas (7), Cumaná (8), Ciudad Bolívar (9) and Mérida (10), and the reports from Ciudad Bolívar and Mérida also describe ESBL-producing isolates detected from communities. In this context and given the increasing probability of dissemination of ESBL-producing strains in the community, the aim of the present study was to characterize multidrug-resistant $E$. coli isolates causing community-acquired urinary tract infections and the risk factors associated with the presence of ESBL in Cumaná, Venezuela.

\section{Materials and methods}

\section{Bacterial isolates and patients}

We evaluated a total of $103 \mathrm{E}$. coli isolates from patients attending the urology outpatient consultation and the emergency unit from January $1^{\text {st }}$ through June $30^{\text {th }}, 2014$, at the Hospital Universitario "Antonio Patricio de Alcalá" in Cumaná, Estado Sucre, Venezuela. Urine samples from patients from both genders (20 males and 83 females) and different 
ages (ranging from 12 to 70 years) who showed urinary tract infection symptoms and indications for urine culture were examined for isolates. All patients were diagnosed with community-acquired urinary tract infection defined as previously suggested (11) as having abundant bacteria and polymorphonuclear leukocytes in the urine sample and positive urine culture with bacterial counts equal to or greater than $10^{3} \mathrm{CFU} / \mathrm{ml}$ of urine when $E$. coli was identified. The urinary tract infections were classified as complicated or uncomplicated according to the guidelines established by the Infectious Diseases Society of America (12).

A community-acquired infection was defined according to the criteria proposed by Friedman, et al. (13), differentiating it from healthcare-associated infections and hospital-acquired infections, like an infection present at the moment of the consultation and when patients had not received any of the following: intravenous therapy at home, wound care or specialized nursing care administered by a healthcare agency, close family or friends, and selfadministered intravenous medical therapy in the 30 days before the infection as well as those patients that did not attend a hospital or hemodialysis clinic, or received intravenous chemotherapy in the previous 30 days, or had been hospitalized in an acute care hospital for two or more days in the previous 90 days, or resided in a nursing home or long-term care facility.

\section{Microbial susceptibility tests and detection of ESBL}

Antimicrobial susceptibility and interpretation were evaluated using the disk diffusion susceptibility test according to the Clinical Laboratory Standards Institute (14). The antimicrobials tested (Oxoid Ltd., UK) were ampicillin $(10 \mu \mathrm{g})$, cefalotin $(30 \mu \mathrm{g})$, cefoxitin $(30 \mu \mathrm{g})$, cefotaxime $(30 \mu \mathrm{g})$, ceftazidime $(30 \mu \mathrm{g})$, cefepime $(30 \mu \mathrm{g})$, aztreonam $(30 \mu \mathrm{g})$, piperacillintazobactam $(100 / 10 \mu \mathrm{g})$, imipenem $(10 \mu \mathrm{g})$, meropenem $(30 \mu \mathrm{g})$, ampiciliin-sulbactam $(10 / 10 \mu \mathrm{g})$ amoxicillin-clavulanic acid $(2: 1)(30 \mu \mathrm{g})$, nalidixic acid $(30 \mu \mathrm{g})$, ciprofloxacin $(5 \mu \mathrm{g})$, amikacin $(30 \mu \mathrm{g})$, tobramycin $(10 \mu \mathrm{g})$ and trimethropim-sulfamethoxazole $(25 \mu \mathrm{g})$.

ESBL phenotypes were confirmed using the combined disc method (14) using E. coli ATCC 25922 and K. pneumoniae ATCC 700603 as the control strains. Multidrug resistance was defined as those isolates that showed resistance to $\geq 1$ agents in $\geq 3$ antimicrobial categories according to the consensus of a group of international experts (15).

\section{Detection of the genes coding for $\beta$-lactamases}

DNA was isolated by extraction using the Wizard Genomic purification

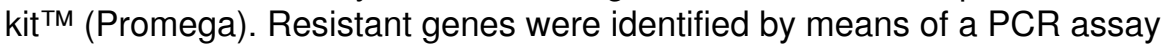
for bla $a_{\mathrm{TEM}}, b / a_{\mathrm{SHV}}$ and bla $a_{\mathrm{CTX}-\mathrm{M}}$ using the primers described elsewhere (16-18). The PCR products were electrophoresed in $2 \%$ agarose gel and stained with GelRed Nucleic Acid Stain ${ }^{\mathrm{TM}}$ (Biotium). A 100 bp DNA ladder (Fermentas, Lithuania) was used as the molecular weight marker.

\section{Transfer of resistance}

Conjugation assays were done in a solid medium using E. coli j622 (resistant to rifampicin, CVCM 131) as the recipient (7). The clinical and recipient strains were grown separately in Luria-Bertani broth (Hardy Diagnostics, Santa Maria, CA, USA) at $37^{\circ} \mathrm{C}$ for 18 hours, and then mixed in a ratio of 1:4 (clinical isolates: recipient). Transconjugants were selected on MacConkey agar containing $100 \mu \mathrm{g}$ rifampicin and $2 \mu \mathrm{g}$ cefalotin. 


\section{Differentiation of the CTX-M group by PCR-RFLP}

Restriction enzyme digestion was carried out according to Mahboobeh (19).The members of the CTX-M group were identified according to the fragments generated by double digestion by the Pstl and Pvull enzymes. E. coli 2944NR was used as an RFLP positive control since it contains aCTX-M-1 type $\beta$-lactamase while E. coli J62-2 was used as a negative control. The RFLP products were observed in a $2 \%$ agarose gel containing GelRedNucleic Acid Stain ${ }^{\mathrm{TM}}$ (Biotium).

\section{Statistical analyses}

The risk factors considered in this study were: Nasogastric tube use, Foley catheter use, chronic kidney disease, cerebral vascular accident, bedridden, immunosuppression treatment, pregnancy, presence of any functional or structural urinary abnormality, diagnosis of a urinary tract infection within one year, antimicrobial treatment within three months, hospitalization within the previous three months but not within the previous 30 days, diabetes, and age over 60.

The risk factors associated with infection by an ESBL-producing $E$. coli isolate were determined firstly by using a binary logistic regression for each variable followed by multivariate analysis for those variables showing best relevance, in which the variables were considered as predictors of ESBL.

The analysis was performed using a stepwise selection of variables, and the area under the ROC curve was calculated to determine the model's predictive ability. The statistical analyses were carried out using the statistical package for the social sciences (SPSS ${ }^{\mathrm{TM}}$, version 18, IBM Corporation).

\section{Ethical aspects}

The patients gave their written consent after they were informed of the risks and benefits of participating in the study and had answered an epidemiological questionnaire.

The treatment of the patients, the analysis of the isolates, and the information generated were conducted according to the bioethical and biosafety guidelines set out by the Comisión de Ética, Bioética y Biodiversidad of the Instituto de Investigaciones en Biomedicina y Ciencias Aplicadas «Dra. Susan Tai" at the Universidad de Oriente.

\section{Results}

The $E$. coli isolates $(n=103)$ evaluated in this study showed high rates of resistance for the antimicrobials frequently used to treat patients with urinary infections, such as ampicillin (96.1\%), cefalotin (59.4\%) and ampicillin-sulbactam (24.8\%), amoxicillin-clavulanate (25.7\%), trimethoprimsulfamethoxazole (39.6\%) and ciprofloxacin (29.7\%).

The isolates from the uncomplicated urinary tract infections (30.1\%) showed significantly lower resistance compared to those from complicated urinary tract infections (figure 1).

A total of $26(25.2 \%)$ isolates were multidrug resistant (table 1), of which 21 (20.4\%) showed production of ESBL. Of the 26 multidrug resistant isolates, 18 showed resistance to six or more antimicrobial categories, and the categories most associated with resistance were penicillins, cephalosporins, both with 


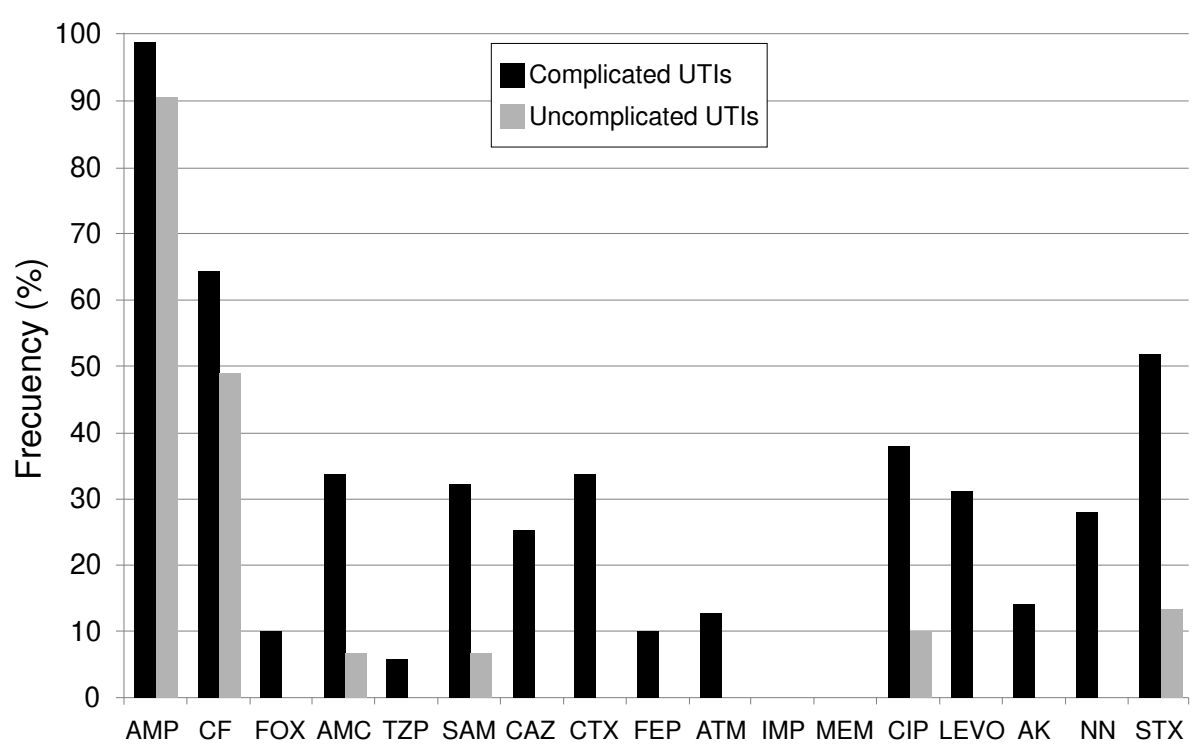

Figure 1. Frequency of resistant Escherichia coli isolates from patients with community-acquired urinary tract infections

AMP: Ampicillin; CF: Cefalotin; FOX: Cefoxitin; AMC: Amoxacillin-clavulanic acid; TZP: Piperacillin-tazobactam; SAM: Ampicillin-sulbactam; CAZ: Ceftazidime; CTX: Cefotaxime; FEP: Cefepime; ATM: Aztreonam; IMP: imipenem; MEM: meropenem; CIP: Ciprofloxacin; LEVO: Levofloxacin; AK: Amikacin; STX: Trimethoprim-sulfamethoxazole

Note: Isolates with intermediate resistance were classified as resistant.

and without extended-spectrum, and folate pathway inhibitors (table 1). ESBLproducing isolates also showed a high frequency (66.7\%) of simultaneous resistance to trimethoprim-sulphamethoxazole, fluoroquinolones and aminoglycosides compared to non-producing isolates (2.4\%).

The bla $_{\text {TEM }}$ gene was found in 17 isolates $(65.4 \%)$ while bla CTX-M $_{\text {mas }}$ wa detected in nine isolates (34.6\%) and $b / a_{\mathrm{SHV}}$ in six isolates (23.1\%). The $b / a_{\mathrm{TEM}}$ and $b l a_{\mathrm{SHV}}$ genes were found in $E$. coli isolates, ESBL-producing or not, while $b_{\text {bTX-M }}$ was only found in ESBL-producing isolates. More than one gene was amplified in seven isolates: The most frequent combination was $b l a_{\mathrm{TEM}}+$ $b a_{\text {CTX-M }}$ (four isolates), and a three-gene combination was found in two ESBL producing isolates (table 1 ). The RFLP results revealed that five of the $b l a_{\text {CTX-M }}$ genes were identified as belonging to the CTX-M-2 group and four to the CTX-M-1 group (figure 2).

Of the 26 multidrug resistant isolates resistant to third generation cephalosporins and subjected to in vitro bacterial conjugation, only 17 were able to transfer plasmids with resistance genes at a mean transfer rate of $10^{-7}$ clinical isolates-transconjugant. Phenotypic analysis of the transconjugants demonstrated that part of the resistance pattern present in the clinical isolates was also observed in the transconjugants (table 1). All of the $b / a_{\text {CTX-M }}$ genes were transferred to the transconjugant strain from the clinical isolates while only $64.7 \%(11 / 17)$ of the $b / a_{\text {TEM }}$ gene and $33.3 \%(2 / 6)$ of the bla $a_{\mathrm{SHV}}$ were transferred (table 1). In the transconjugants of the two clinical isolates containing the three genes (204 and 339), the bla ${ }_{\mathrm{SHV}}$ gene was not transferred. These results demonstrate the transmissibility of bla genes to other E. coli strains.

When analyzing the risk factors for ESBL-producing $E$. coli, we found that an age over 60 years, complicated urinary tract infection, and urinary 
Table 1. Phenotypic and molecular characteristics of multidrug resistant Escherichia coli isolates. Here we show the DDST phenotypes of the bacterial isolates from patients with community-acquired urinary tract infections and their transconjugants, when appropriate, as well as the genes detected by PCR.

\begin{tabular}{|c|c|c|c|c|c|}
\hline Isolates & ESBL & Resistance & Bla genes & Resistance in transconjugants & $\begin{array}{l}\text { Bla genes } \\
\text { transferred }\end{array}$ \\
\hline EC14 & + & AMP, CF, CAZ, CTX, STX & $b l a_{\text {TEM }}$ & & \\
\hline EC33 & - & AMP, CF, FOX, CTX, ATM, CIP, LEVO, STX & $b l a_{\mathrm{SHV}}$ & & \\
\hline EC37 & - & AMP, CF, CTX, CIP, STX & - & & \\
\hline EC49 & - & $\begin{array}{l}\text { AMP, CF, AMC, CAZ, CTX, ATM, CIP, LEVO, AK, } \\
\text { TOB, STX, }\end{array}$ & $b l a_{\mathrm{TEM}}$ & & \\
\hline EC95 & + & AMP, CF, AMC, CAZ, CTX, CIP, LEVO, STX & $b l a_{\mathrm{SHV}}$ & & \\
\hline EC190 & - & AMP, CF, CAZ, NAL, CIP, LEVO, STX & $b l a_{\text {TEM }}$ & & \\
\hline EC305 & - & $\begin{array}{l}\text { AMP, CF, AMC, CTX, ATM, SAM, CIP, LEVO, } \\
\text { AK, TOB, STX }\end{array}$ & $b l a_{\text {TEM }}$ & & \\
\hline EC372 & + & AMP, CF, CAZ, CTX, FEP, CIP, STX & $b l a_{\text {TEM }}$ & & \\
\hline EC918 & + & AMP, CF, CAZ, CTX, FEP, CIP, LEVO & $b / a_{\text {TEM }}$ & & \\
\hline EC16 & + & AMP, CF, CAZ, CTX, SAM, STX & $b l a_{\mathrm{TEM}}$ & AMP, CF, CAZ, CTX, STX & blaTEM \\
\hline EC30 & + & AMP, CF, CTX, SAM, CIP, TOB, STX & $b l a_{\text {TEM }}, b l a_{\text {CTX-M }}$ & AMP, CF, CTX, TOB, STX & blaTEM, blaCTX-M \\
\hline EC61 & + & $\begin{array}{l}\text { AMP, CF, AMC, FOX, CAZ, CTX, SAM, CIP, } \\
\text { LEVO, AK, TOB, STX }\end{array}$ & $b l a_{\mathrm{TEM}}, b l a_{\mathrm{CTX}-\mathrm{M}}$ & AMP, CF, CTX, AK, TOB, STX & blaTEM, blaCTX-M \\
\hline EC78 & + & AMP, CF, CTX, SAM, CIP, LEVO, TOB, STX & $b l a_{\text {TEM }}$ & AMP, CF, CTX, TOB, STX & blaTEM \\
\hline EC84 & + & AMP, CF, CTX, SAM, CIP, TOB, STX & $b l a_{\text {TEM }}$ & AMP, CF, CTX, STX & blaTEM \\
\hline EC123 & + & AMP, CF, CAZ, CTX, FEP CIP, LEVO, TOB, STX & $b l a_{\mathrm{SHV}}$ & AMP, CF, CAZ, CTX, FEP, TOB, STX & blaSHV \\
\hline EC204 & + & $\begin{array}{l}\text { AMP, CF, AMC, CTX, ATM, CIP, LEVO, TOB, } \\
\text { STX }\end{array}$ & $b l a_{\mathrm{TEM}}, b l a_{\mathrm{SHV}}, b l a_{\mathrm{CTX}-\mathrm{M}}$ & AMP, CF, CTX, TOB, STX & blaTEM, blaCTX-M \\
\hline EC339 & + & $\begin{array}{l}\text { AMP, CF, AMC, FOX, CAZ, CTX, ATM, SAM, } \\
\text { CIP, LEVO, AK, TOB, STX }\end{array}$ & $b l a_{\mathrm{TEM}}, b l a_{\mathrm{SHV}}, b l a_{\mathrm{CTX}-\mathrm{M}}$ & AMP, CF, CAZ, CTX, ATM, AK, TOB, STX & blaTEM, blaCTX-M \\
\hline EC347 & + & $\begin{array}{l}\text { AMP, CF, AMC, CAZ, CTX, FEP, SAM, CIP, } \\
\text { LEVO, AK, TOB }\end{array}$ & $b l a_{\text {CTX-M }}$ & $\begin{array}{l}\text { AMP, CF, CAZ, CTX, FEP, NAL, CIP, AK, } \\
\text { TOB }\end{array}$ & blaCTX-M \\
\hline EC348 & + & $\begin{array}{l}\text { AMP, CF, AMC, CAZ, CTX, FEP, SAM, CIP, } \\
\text { LEVO, TOB, STX }\end{array}$ & $b l a_{\mathrm{TEM}}, b l a_{\mathrm{SHV}}$ & AMP, CF, CAZ, CTX, FEP, TOB, STX & blaTEM, blaSHV \\
\hline EC385 & + & $\begin{array}{l}\text { AMP, CF, AMC, FOX, CAZ, CTX, ATM, SAM, } \\
\text { CIP, LEV, TOB }\end{array}$ & - & AMP, CF, CAZ, CTX, TOB & - \\
\hline EC514 & + & $\begin{array}{l}\text { AMP, CF, AMC, FOX, CAZ, CTX, ATM, SAM, } \\
\text { CIP, LEVO, TOB, STX }\end{array}$ & $b l a_{\text {CTX-M }}$ & AMP, CF, CAZ, CTX, ATM, TOB, STX & blaCTX-M \\
\hline EC779 & + & AMP, CF, CAZ, CIP, LEVO, STX & - & AMP, CF, CAZ & - \\
\hline EC868 & + & AMP, CF, AMC, CTX, CIP, LEVO, STX & $b l a_{\mathrm{TEM}}, b l a_{\mathrm{CTX}-\mathrm{M}}$ & AMP, CF, AMC, CTX & blaTEM, blaCTX-M \\
\hline EC876 & + & $\begin{array}{l}\text { AMP, CF, CAZ, CTX, PTZ, FEP, CIP, LEVO, AK, } \\
\text { TOB, STX }\end{array}$ & $b l a_{\text {TEM }}$ & AMP, CF, CAZ, CTX, FEP, AK, TOB, STX & blaTEM \\
\hline EC926 & + & $\begin{array}{l}\text { AMP, CF, AMC, CAZ, CTX, ATM, SAM, CIP, } \\
\text { LEVO, AK, TOB, STX }\end{array}$ & $b l a_{\text {TEM }}, b l a_{\text {CTX-M }}$ & $\begin{array}{l}\text { AMP, CF, CAZ, CTX, NAL, CIP, AK, TOB, } \\
\text { STX }\end{array}$ & blaTEM, blaCTX-M \\
\hline EC983 & + & $\begin{array}{l}\text { AMP, CF, AMC, CAZ, CTX, ATM, FEP, CIP, } \\
\text { LEVO, AK, TOB, STX }\end{array}$ & $b l a_{\text {CTX-M }}$ & $\begin{array}{l}\text { AMP, CF, CAZ, CTX, ATM, FEP, AK, TOB, } \\
\text { STX }\end{array}$ & blaCTX-M \\
\hline
\end{tabular}

ESBL: Extended-spectrum $\beta$-lactamases; AMP: Ampicillin; CF: Cefalotin; AMC: Amoxacillin-clavulanic acid; FOX: Cefoxitin; CAZ: Ceftazidime; CTX: Cefotaxime; ATM: Aztreonam; SAM: Ampicillin-sulbactam; TZP: Piperacillin-tazobactam; FEP: Cefepime; CIP: Ciprofloxacin; LEVO: Levofloxacin; AK: Amikacin; TOB: Tobramycin; STX: Trimethoprim-sulfamethoxazole

catheterization (more than 30 days previous to the infection) predisposed patients to an infection by a multidrug resistant/ESBL-producing $E$. coli strain (table 2) with relative risks (RR) $3.1(95 \% \mathrm{Cl}: 1.5-6.4)$, $4.1(95 \% \mathrm{Cl}: 1.1-$ 16.5), and 3.3 (95\% Cl: 1.6-6.8) times higher, respectively, for patients with those conditions compared to those without them.

Other risk factors, such as nasogastric tube use, cerebral vascular accident, bedridden patients, immunosuppression treatment, pregnancy, the presence of a structural urinary abnormality, and hospitalization within the previous three months were not analyzed since no ESBL-producing isolate was found in any of the patients showing these conditions. 


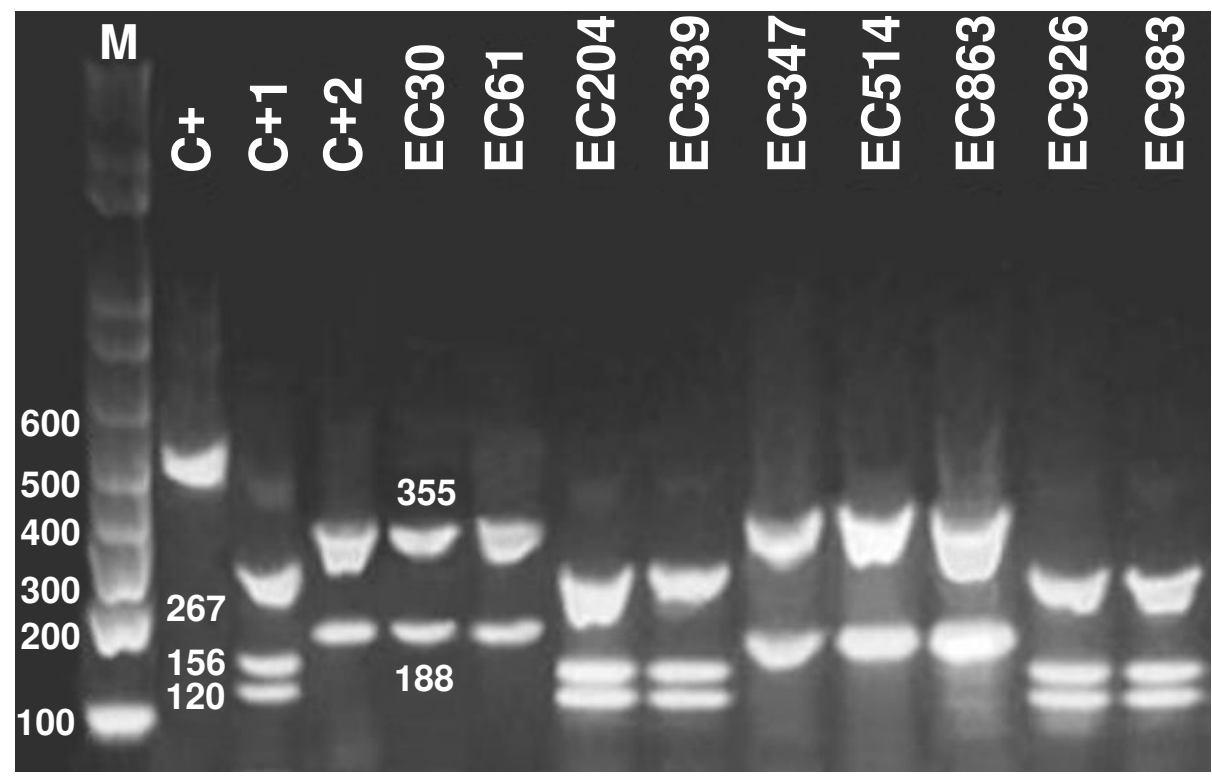

Figure 2. Digestion profile of the bla ${ }_{\text {CTX-M }}$ gene detected in Escherichia coli isolated from patients with community-acquired urinary infections

M: Molecular weight marker (1 kb Invitrogen); C+: Undigested bla ${ }_{\text {CTX-M-2 }}$ fragment; C+1: Control bla ${ }_{\text {CTX-M-1 }}$, strain

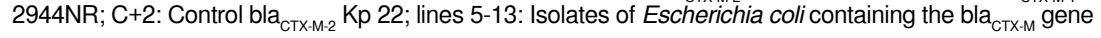

Table 2. Epidemiological and clinical variables associated with ESBL-producing Escherichia coli

\begin{tabular}{|c|c|c|c|c|c|}
\hline Risk factors & $\mathbf{n}$ & $\begin{array}{c}\text { ESBL + } \\
(n=21)\end{array}$ & $\begin{array}{l}\text { ESBL - } \\
(n=82)\end{array}$ & $\mathbf{p}$ & $\begin{array}{c}\text { RR } \\
(95 \% \mathrm{Cl})\end{array}$ \\
\hline Male gender & 20 & 9 & 11 & 0.962 & \\
\hline Age $>60$ years & 20 & 9 & 11 & $0.002^{*}$ & $\begin{array}{c}3.1 \\
(1.5-6.4)\end{array}$ \\
\hline Complicated urinary tract infection & 72 & 19 & 53 & 0.048 & $\begin{array}{c}4.1 \\
(1.1-16.5)\end{array}$ \\
\hline Recurrent urinary tract infection & 38 & 5 & 33 & 0.183 & \\
\hline Previous ( 30 days) urinary catheterization & 11 & 6 & 5 & $0.001^{*}$ & $\begin{array}{c}3.3 \\
(1.6-6.8)\end{array}$ \\
\hline Previous empiric treatment with first line beta-lactams $\mathrm{s}^{\mathrm{a}, \mathrm{b}}$ & 35 & 13 & 28 & 0.134 & \\
\hline Treatment with extended spectrum cephalosporins $s^{a, c}$ & 28 & 5 & 23 & 0.313 & \\
\hline Renal lithiasis & 32 & 7 & 25 & 0.603 & \\
\hline Renal impairment & 12 & 2 & 10 & 0.493 & \\
\hline Diabetes & 29 & 9 & 20 & 0.389 & \\
\hline
\end{tabular}

ESBL: Extended spectrum $\beta$-lactamases; RR: Relative risk; $\mathrm{Cl}$ : Confidence interval

* Statistically significant

a Within three months

${ }^{b}$ First line $\beta$-lactams: AMP, SAM, and CF

${ }^{c}$ Extended spectrum cephalosporins: 3rd and 4th generation cephalosporins and monobactams (ATM)

Of the 20 male patients with complicated urinary tract infections, seven were aged over 60 with functional problems due to their prostate or kidneys and frequently attended the urology consultation for their control. All seven patients had urinary tract infections caused by ESBL-producing isolates. Of the 83 female patients with urinary tract infections, 53 were classified as complicated due to any of the abovementioned factors but with recurrent urinary tract infections within a year being the most frequent condition. 


\section{Discussion}

The resistance of $E$. coli isolates from complicated urinary tract infections to many of the antimicrobials tested here indicates that treatment should only be given after susceptibility testing. High resistant rates to third-generation cephalosporins and aztreonam of clinical isolates of another bacteria, $K$. pneumoniae, have also been found in a previous study undertaken in Cumaná (12). The relatively high frequency of multidrug resistant $E$. coli found in the community and the high proportion of isolates showing resistance to $\geq 6$ antimicrobials indicates the need to revise the treatment guidelines for urinary tract infections in Venezuela. A significant increase in the prevalence of multidrug resistant $E$. coli has also been reported in the US with rates raising from $9.1 \%$ in 2001 to $17.0 \%$ in 2010 (20) and resistance to three, four or five antimicrobial agents. In the same study, widespread resistance was observed for trimethoprim-sulfamethoxazole $(62.6 \%, 88.6 \%$, and $97.9 \%$, respectively) and ciprofloxacin (48.9\%, 84.3\%, and $98.2 \%$, respectively).

Uncomplicated community-acquired urinary tract infections are normally treated empirically without undertaking a urine culture or an antibiogram unless they recur repeatedly (21). Our findings, however, demonstrate the importance of monitoring this empirical use of antimicrobials at a community level as recommended by the Infectious Diseases Society of America in order to select an appropriate empirical treatment (22).

$\beta$-lactam antibiotics are commonly the first choice of treatment against many microorganisms including uropathogens. Nevertheless, in recent years there has been a progressive increase in the frequency of $E$. coli strains from outpatients that characteristically show reduced susceptibility to penicillins and third generation cephalosporins due to the production of ESBL (23). This is now considered an emergent problem at the community level especially as changes in epidemiological patterns have been observed: While SHV and TEM have been shown to be the most prevalent enzymes in nosocomial strains, CTX-M is reported as predominant in community-acquired strains (24).

In this study, phenotypic characterization revealed that an important fraction of the isolates studied produced ESBLs. Here, the $b / a_{\mathrm{TEM}}$ gene was the most prevalent ESBL gene indicating the possible circulation of TEM-type ESBLs in strains from the community that have not been detected in nosocomial strains from the Hospital General de Cumaná (12). We also found variations in the antibiotic

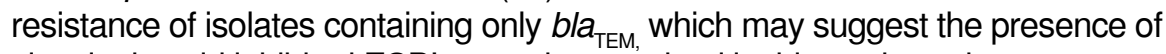
clavulanic-acid inhibited ESBLs not characterized in this study, or the presence of other $b / a_{\mathrm{TEM}}$ type genes. The non-ESBL-producing isolates that did contain the $b l a_{\text {TEM }}$ gene are probably TEM- 1 that confers resistance to penicillins and firstgeneration cephalosporins. Resistance to third-generation cephalosporins could then be due to other resistance mechanisms, for example, OXA-type enzymes which have been identified from some $E$. coli strains isolated from patients with community-acquired urinary tract infections in India (25). The bla ${ }_{\mathrm{SHV}}$ gene has been found to be less frequent in community-based strains than $b a_{\mathrm{TEM}}$ and $b l a_{\mathrm{CTX}-\mathrm{M}}$ (26).

The identification of the specific CTX-M enzyme type from the susceptibility pattern proved to be difficult due to the overlapping of the ceftazidime and cefotaxime phenotypes and the fact that several genes were present. The wide dissemination of CTX-Ms around the world has been referred to as the "CTX-M pandemic" since this enzyme is the most common $\beta$-lactamase carried by the Enterobacteriaceae that cause community onset urinary tract infections as shown in reports from different continents $(2,24,27-31)$. 
In Venezuela, there have been very few reports that identify the type of bla genes found in bacterial strains causing urinary infections. The CTX-M-32 enzyme (CTX-M-1) was identified in an E. coli strain isolated from a patient with diabetes from the Mérida state who was also suffering from a community-acquired urinary tract infection, which is the first report of this variant in South America (32).

It is important to note that some CTX-M enzymes are associated with specific countries: CTX-M-9 in Spain; CTX-M-1 in Italy and the United Kingdom, and CTX-M-2 in Israel, Japan, and most South American countries $(24,33)$. In contrast, variants such as CTX-M-15 (CTX-M-1), which originated from the Asp240Gly substitution in CTX-M-3 and CTX-M-14 have been detected all over the world $(24,34)$. The seasonal appearance and spread of these enzymes in different habitats may partially explain their epidemiology. The use of antimicrobials and other risk factors in different regions, as well as the characteristics of different geographical compartments, may have contributed to the current situation surrounding CTX-M.

The in vitro bacterial conjugation assays demonstrated that the genes coding for ESBL are localized in transferable plasmids which also carry other resistance determinants affecting antimicrobials, such as aminoglycosides, trimethoprim-sulfamethoxazole, and quinolones. Furthermore, the transfer of resistance to ciprofloxacin and nalidixic acid indicates that these strains contain a resistance mechanism against this group of antimicrobials that can disseminate horizontally as well as vertically. In India, 94\% of the CTXM-producing isolates were able to transfer their genes by conjugation with plasmids ranging in size from 120 to $272 \mathrm{kbp}$ and half of these plasmids also carried the TEM-1 gene (25). This dissemination of ESBL in conjugative plasmids increases the possibility of an accelerated rate of proliferation (2).

Few studies have evaluated risk factors for community-onset ESBL infections and some of the studies previously undertaken in the U.S.A. were conducted prior to the emergence of community-wide multidrug-resistant $E$. coli (35). Here we identified age over 60 years, complicated urinary tract infections, and urinary catheterization as risk factors for infection with ESBL-producing $E$. coli strains. Other studies have also shown older age (35-40), urinary catheterization $(36,37,39)$ and complicated urinary tract infections $(40)$ as factors that increase the risk of acquiring a urinary tract infection by multidrug resistant bacteria.

In conclusion, our results reveal the presence of multidrug resistant isolates that cause community-acquired urinary infections. This is of great epidemiological importance and requires the intervention of the health authorities in the region to prevent further dissemination of these types of strains.

\section{Acknowledgements}

We would like to thank the staff of the clinical bacteriology laboratory at the Hospital Universitario "Antonio Patricio de Alcalá": Belkis Medina, Dianny Martínez, Lucy Rodríguez, José Antonio Barreto, Luisa Caña, Jose García, Diorelis González, Maylim Mundaray, and Verónica Peinado, for the support and effort they always give to research activities and the key role that they play in fighting against bacterial infections.

\section{References}

1. Laupland KB, Ross T, Pitout JD, Church DL, Gregson DB. Community-onset urinary tract infections: A population-based assessment. Infection. 2007;35:150.

https://doi.org/10.1007/s15010-007-6180-2 
2. Peirano G, Pitout JD. Molecular epidemiology of Escherichia coli producing CTX-M B-lactamases: The worldwide emergence of clone ST131 O25: H4. Int J Antimicrob Agents. 2010;35:316-21. https://doi.org/10.1016/j.jjantimicag.2009.11.003

3. Guzmán-Blanco M, Labarca JA, Villegas MV, Gotuzzo E. Extended spectrum $\beta$-lactamase producers among nosocomial Enterobacteriaceae in Latin America. Braz J Infect Dis. 2014;18:421-33. https://doi.org/10.1016/j.bjid.2013.10.005

4. Cantón R, González-Alba JM, Galán JC. CTX-M enzymes: Origin and diffusion. Front Microbiol. 2012;3:110. https://doi.org/10.3389/fmicb.2012.00110

5. Bonnet R. Growing group of extended-spectrum $\beta$-lactamases: The CTX-M enzymes. Antimicrob Agents Chemother. 2004;48:1-4. https://doi.org/10.1128/AAC.48.1.1-14.2004

6. Dhillon $\mathrm{RH}$, Clark J. ESBLs: A clear and present danger? Crit Care Res Pract. 2012;2012:625170. https://doi.org/10.1155/2012/625170

7. Narváez P, Pedroza R, Alonso G, Rodríguez-Lemoine V. Caracterización de plásmidos de resistencia a antibióticos en aislados nosocomiales del Hospital Universitario de Caracas. Rev Soc Ven Microbiol. 2005;25:29-34.

8. Guzmán M, Alonso G. Caracterización de B-lactamasas de espectro extendido (BLEE) en cepas nosocomiales de K. pneumoniae. Sucre-Venezuela. Invest Clin. 2009;50:419-31.

9. Guevara A, Machado S, Manrique E. Urinary infections acquired in community: Epidemiology, resistance to antibiotics and therapeutic options. Kasmera. 2011;39:87-97.

10. Hernández E, Araque M, Millán Y, Millán B, Vielma S. Prevalencia de $\beta$-lactamasa CTX-M-15 en grupos filogenéticos de Escherichia coli uropatógena aisladas en pacientes de la comunidad en Mérida, Venezuela. Invest Clin. 2014;55:32-43.

11. de Cueto M. La microbiología en el diagnóstico de la infección del tracto urinario. In: Pigrau C, editor. Infección del tracto urinario. Primera edición. Madrid: Salvat; 2013. p. 11-22.

12. Nicolle LE, Bradley S, Colgan R, Rice JC, Schaeffer A, Hooton TM. Infectious Diseases Society of America guidelines for the diagnosis and treatment of asymptomatic bacteriuria in adults. Clin Infect Dis. 2005;40:643-54. https://doi.org/10.1086/427507

13. Friedman ND, Kaye KS, Stout JE, McGarry SA, Trivette SL, Briggs JP, et al. Health careassociated bloodstream infections in adults: A reason to change the accepted definition of community-acquired infections. Ann Intern Med. 2002;137:791-7. https://doi.org/10.7326/0003-4819-137-10-200211190-00007

14. Clinical and Laboratory Standards Institute. Performance standards for antimicrobial susceptibility testing; twenty-four informational supplement, M100-S24. Wayne, PA: CLSI; 2014. p. 226.

15. Magiorakos AP, Srinivasan A, Carey RB, Carmeli Y, Falagas ME, Giske CG, et al. Multidrugresistant, extensively drug-resistant and pandrug-resistant bacteria: An international expert proposal for interim standard definitions for acquired resistance. Clin Microbiol Infect. 2012;18:268-81. https://doi.org/10.1111/j.1469-0691.2011.03570.x

16. Eckert C, Gautier V, Saladin-Allard M, Hidri N, Verdet C, Ould-Hocine Z, et al. Dissemination of CTX-M- type beta-lactamases among clinical isolates of Enterobacteriaceae in Paris, France. Antimicrob Agents Chemother. 2004;48:1249-55. https://doi.org/10.1128/AAC.48.4.1249-1255.2004

17. Haeggman S, Löfdal S, Poauw A, Verhoef J, Brisse S. Diversity and evolution of the class A chromosomal beta-lactamase gene in Klebsiella pneumoniae. Antimicrob Agents Chemother. 2004;48:2400-8. https://doi.org/10.1128/AAC.48.7.2400-2408.2004

18. Eldestein M, Pimkin M, Palagin I, Eldestein I, Stratchounski L. Prevalence and molecular epidemiology of CTX-M extended spectrum $\beta$-lactamase-producing Escherichia coli and Klebsiella pneumoniae in Russian hospitals. Antimicrob Agents Chemother. 2003;47:372432. https://doi.org/10.1128/AAC.47.12.3724-3732.2003

19. Mahboobeh N, Forghanifard M, Moshrefi S. Prevalence and molecular characterization of plasmid-mediated extended-spectrum $\beta$-lactamase genes $\left(b_{\text {TEM }}, b / a_{\mathrm{CTX}}\right.$ and $\left.b l a_{\mathrm{SHV}}\right)$ among urinary Escherichia coli clinical isolates in Mashhad, Iran. Iran J Basic Med Sci. 2012;15:833-9.

20. Sánchez GV, Baird AM, Karlowsky JA, Master RN, Bordon JM. Nitrofurantoin retains antimicrobial activity against multidrug-resistant urinary Escherichia coli from US outpatients. J Antimicrob Chemother. 2014;69:3259-62. https://doi.org/10.1093/jac/dku282

21. Alos Jl. Epidemiología y etiología de la infección urinaria comunitaria. Sensibilidad antimicrobiana de los principales patógenos y significado clínico de la resistencia. Enferm Infecc Microbiol Clin. 2005;23:3-8. https://doi.org/10.1157/13091442 
22. Spellberg B, Talbot G, Brass E, Bradley J, Boucher H, Gilbert D, et al. Position paper: Recommended design features of future clinical trials of antibacterial agents for communityacquired pneumonia. Clin Infect Dis. 2008;47(Suppl.3):S249-65. https://doi.org/10.1086/591411

23. Winokur PL, Canton R, Casellas JM, Legakis N. Variations in the prevalence of strains expressing an extended-spectrum beta-lactamase phenotype and characterization of isolates from Europe, the Americas, and the Western Pacific Region. Clin Inf Dis. 2001;32(Suppl.2):S94-103. https://doi.org/10.1086/320182

24. Canton R, Coque T. The CTX-M beta-lactamase pandemic. Curr Opin Microbiol. 2006;9:466-75. https://doi.org/10.1016/j.mib.2006.08.011

25. Hussain A, Ewers C, Nandanwar N, Guenther S, JadhavS, Wieler LH, et al. Multiresistant uropathogenic Escherichia coli from a region in India where urinary tract infections are endemic: Genotypic and phenotypic characteristics of sequence type 131 isolates of the CTX-M-15 extended-spectrum-beta-lactamase-producing lineage. Antimicrob Agents Chemother. 2012;56:6358. https://doi.org/10.1128/AAC.01099-12

26. Ben-Ami R, Rodríguez-Baño J, Arslan H, Pitout JD, Quentin C, Calbo ES, et al. A multinational survey of risk factors for infection with extended-spectrum beta-lactamaseproducing enterobacteriaceae in nonhospitalized patients. Clin Infect Dis. 2009;49:682-90. https://doi.org/10.1086/604713

27. Ahmed O, Alfadel O, Asghar H, Elhassan M. Prevalence of TEM, SHV and CTX-M genes in Escherichia coli and Klebsiella spp. urinary isolates from Sudan with confirmed ESBL phenotype. Life Sci J. 2013;10:191-5.

28. Radice M, Power P, Di Conza J, Gutkind G. Early dissemination of CTX-M-derived enzymes in South America. Antimicrob Agents Chemother. 2002;46:602-4. https://doi.org/10.1128/AAC.46.2.602-604.2002

29. Wang H, Kelkar S, Wu W, Chen M, Quinn J. Clinical isolates of Enterobacteriaceae producing extended-spectrum b-lactamases: Prevalence of CTX-M-3 at a hospital in China. Antimicrob Agents Chemother 2003;47:790-3. https://doi.org/10.1128/AAC.47.2.790-793.2003

30. Yamasaki K, Komatsu M, Yamashita T, Shimakawa K, Ura T, Nishio H, et al. Production of CTX-M-3 extended-spectrum beta-lactamase and IMP-1 metallo beta-lactamase by five Gramnegative bacilli: Survey of clinical isolates from seven laboratories collected in 1998 and 2000, in the Kinki region of Japan. J Antimicrob Chemother. 2003;51:631-8. https://doi.org/10.1093/jac/dkg103

31. Kung CH, Ku WW, Lee $\mathrm{CH}$, Fung CP, Kuo SC, Chen TL, et al. Epidemiology and risk factors of community-onset urinary tract infection caused by extended-spectrum $\beta$-lactamaseproducing Enterobacteriaceae in a medical center in Taiwan: A prospective cohort study. $\mathrm{J}$ Microbiol Immunol Infect. 2015;48:168-74. https://doi.org/10.1016/j.jmii.2013.08.006

32. Araque M, Millán B, Mendoza E, Salas M. CTX-M-32 beta-lactamase-producing uropathogenic Escherichia coli isolated in Latin America. J Infect Dev Ctries. 2013;7:432-5. https://doi.org/10.3855/jidc.3488

33. Coque T, Baquero F, Cantón R. Increasing prevalence of ESBL-producing enterobacteriaceae in Europe. Eurosurveillance. 2008;47:19-29. https://doi.org/10.2807/ese.13.47.19044-en

34. Rossolini G, D'Andrea M, Mugnaioli C. The spread of CTX-M-type extended-spectrum betalactamases. Clin Microbiol Infect. 2008;14:33-41. https://doi.org/10.1111/j.1469-0691.2007.01867.x

35. Banerjee R, Strahilevitz J, Johnson JR, Nagwekar PP, Schora DM, Shevrin I, et al. Predictors and molecular epidemiology of community-onset extended-spectrum $\beta$-lactamase-producing Escherichia coli infection in a Midwestern community. Infect Control Hosp Epidemiol. 2013;34:947-53. https://doi.org/10.1086/671725

36. Blanco VM, Maya JJ, Correa A, Perenguez M, Muñoz JS, Motoa G, et al. Prevalencia y factores de riesgo para infecciones del tracto urinario de inicio en la comunidad causadas por Escherichia coli productor de betalactamasas de espectro extendido en Colombia. Enferm Infecc Microbiol Clin. 2016;34:559-65. https://doi.org/10.1016/j.eimc.2015.11.017

37. Kronenberg A, Hilty M, Endimiani A, Muhlemann K. Temporal trends of extended-spectrum cephalosporin-resistant Escherichia coli and Klebsiella pneumoniae isolates in in- and outpatients in Switzerland, 2004 to 2011. Euro Surveill. 2013;18:20484.

https://doi.org/10.2807/ese.18.21.20484-en 
38. Anesi JA, Lautenbach E, Nachamkin I, Garrigan C, Bilker WB, Wheeler M, et al. Clinical and molecular characterization of community-onset urinary tract infections due to extendedspectrum cephalosporin-resistant Enterobacteriaceae. Infect Control Hosp Epidemiol. 2016;37:1433-9. https://doi.org/10.1017/ice.2016.225

39. Bours PH, Polak R, Hoepelman Al, Delgado E, Jarquin A, Matute AJ. Increasing resistance in community-acquired urinary tract infections in Latin America, five years after the implementation of national therapeutic guidelines. Int J Infect Dis. 2010;14:e770-4. https://doi.org/10.1016/j.ijid.2010.02.2264

40. Seija V, Fratchez V, Ventura V, Pintos M, González M. Factores asociados al desarrollo de infección urinaria de origen comunitario causada por Escherichia coli resistente a fluoroquinolonas. Rev Chilena Infectol. 2014;31:400-5.

https://doi.org/10.4067/S0716-10182014000400004 